\title{
STUDI AKTIVITAS ENZIM PENCERNAAN LARVA IKAN KUWE, Gnathanodon speciosus YANG DIPELIHARA DENGAN JENIS PAKAN AWAL BERBEDA
}

\author{
Titiek Aslianti dan Afifah \\ Balai Besar Penelitian dan Pengembangan Budidaya Laut \\ Jl. Br. Gondol Kec. Gerokgak Kab. Buleleng, Kotak Pos 140, Singaraja- Bali 81101 \\ E-mail: tiaspriyono@yahoo.com
}

(Naskah diterima: 31 Oktober 2011; Disetujui publikasi: 16 Maret 2012)

\begin{abstract}
ABSTRAK
Upaya kontinuitas produksi benih ikan kuwe, Gnathanodon speciosus telah dilakukan namun sintasan yang diperoleh belum stabil. Jenis dan ukuran pakan pada larva stadia awal seringkali menjadi penyebab utama kegagalan produksi benih. Aktivitas enzim pencernaan diketahui sangat terkait dengan jenis pakan yang dikonsumsi larva sehingga berdampak terhadap pertumbuhan dan sintasannya. Enzim protease, amilase, dan lipase merupakan indikator biologis yang dapat menunjukkan kesesuaian jenis pakan yang dikonsumsi larva melalui kemampuannya untuk mencerna. Penelitian bertujuan untuk mengetahui aktivitas enzim pencernaan larva ikan kuwe yang diberi ransum pakan awal berbeda yaitu rotifer, gonad kerang, dan kuning telur ayam. Penelitian dilakukan dengan menggunakan rancangan acak lengkap 3 perlakuan dengan 3 ulangan. Hasil penelitian menunjukkan bahwa aktivitas enzim protease, amilase, dan lipase pada ketiga perlakuan mempunyai korelasi positif terhadap pertumbuhan. Aktivitas enzim pencernaan cenderung meningkat pada saat larva mulai menerima pakan eksogen (D-2), kemudian menurun pada D-3-D- 7 selanjutnya relatif stabil hingga akhir penelitian (D-30). Pakan awal kuning telur menghasilkan pertumbuhan $(T L=13,3 \pm 1,77 \mathrm{~mm})$ dan sintasan benih $(55,42 \%)$ paling tinggi daripada rotifer $(T L=10,6 \pm 1,51 \mathrm{~mm}$; SR 52,42\%) maupun gonad kerang $(T L=12,7 \pm 2,67 \mathrm{~mm}$; $52,45 \%$. Hasil penelitian diharapkan dapat meningkatkan produksi benih sebagai pasok yang kontinu dalam mendukung pengembangan budidaya.
\end{abstract}

KATA KUNCl: aktivitas enzim pencernaan, ikan kuwe, larva, pakan awal

ABSTRACT: Study of the digestive enzyme activity of Gnathanodon speciosus larvae fed by different initial feeds. By: Titiek Aslianti and Afifah

Seed production continuity of Gnathanodon speciosus had been conducted, but the results were still un-consistent. Inability of initial feed is the main problem unsuccessful seed production. The enzymatic function of larval digestive tract has correlation with feeding consumed and it affected to growth and survival rate. Protease, amylase, and lipase enzymes were used as a biological indicator to measure the digestion of feed. The aim of this study was to describe digestive enzyme activity of larvae with different initial feed. The experiment was conducted in a completely randomized design consisted of 3 treatments in terms of different initial feed i.e., rotifer, trochopore gonad, and egg yolk emulsion with 3 replicates each. The result of the study showed that the enzymes activity (protease, amylase, and lipase) of the different initial feed were positively correlated with the growth. Digestive enzymes activity was increased 
when larvae started on exogenous feed (D-2), becomes down on $D-3-D-7$ and there were stabilized while the research was terminated on D-30. Egg yolk emulsion feed gave the highest growth $(T L=13.3 \pm 1.77 \mathrm{~mm})$ and survival rate $(55.42 \%)$ than rotifer $(T L=10.6 \pm 1.51 \mathrm{~mm} ; 52.42 \%)$ or trochopore $(T L=12.7 \pm 2.67 \mathrm{~mm} ; 52.45 \%)$. Result of the experiment could be supported continuity seed production as supplies for aquaculture development.

\section{KEYWORDS: digest enzyme activity, golden trevally, initial feed, larvae}

\section{PENDAHULUAN}

Ikan kuwe dari jenis Golden trevally, Gnathanodon speciosus (Forsskal) termasuk jenis ikan karang yang relatif mudah dibudidayakan (Kordi, 2005) dan mempunyai pangsa pasar cukup tinggi sehingga sangat prospektif dalam mendukung pengembangan budidaya laut (Peristiwadi, 2006). Ikan kuwe selain diminati untuk konsumsi juga berpotensi sebagai ikan hias terutama pada ukuran yuwana $(5-10 \mathrm{~cm}$ ) yang dikenal dengan nama Pidana kuning atau Simbha kuning (Hadi, 2009). Gerak renang yang lincah dengan warna cerah kuning keemasan serta terdapat lebih dari 10 garis hitam yang melingkar vertikal pada badan (Shobo, 1991) menambah nilai estetika tersendiri sehingga harga jualnya meningkat.

Upaya produksi massal benih secara terkontrol telah dilakukan melalui berbagai penelitian yang mengarah pada peningkatan sintasan guna mendukung kontinuitas pasok benih (Setiadharma et al., 2008). Namun, kegagalan produksi benih masih sering dialami terutama disebabkan tidak sesuainya jenis pakan pada stadia awal sehingga tingkat kematian cukup tinggi (Hadi, 2009). Pakan merupakan unsur utama yang mempengaruhi pertumbuhan dan sintasan benih. Fungsi pakan pada ikan sangat terkait dengan aktivitas enzim pencernaan yang dipengaruhi oleh ukuran (fisiologis), umur, dan organ spesifik ikan selama fase pertumbuhan, serta musim (Hepher, 1988). Peningkatan aktivitas enzim pencernaan akan sejalan dengan pertumbuhan larva. Demikian halnya perbedaan kualitas pakan yang diberikan selama pemeliharaan akan memberikan ekspresi aktivitas enzimatik yang berbeda pula.

Aktivitas enzimatik pada sistem pencernaan larva ikan stadia awal umumnya masih sangat sederhana, diduga sangat terkait dengan kemampuan larva untuk mencerna pakan yang dikonsumsinya (Suryanti, 2002). Dikatakan pula bahwa enzim protease, amilase, dan lipase merupakan indikator biologis untuk menge- tahui kemampuan larva dalam mencerna pakan yang diterimanya. Stadia awal larva ikan kuwe pada saat mulai menerima ransum pakan eksogen merupakan masa kritis yang seringkali menyebabkan kematian massal (Afifah et al., 2010). Kesesuaian jenis, ukuran, dan kandungan nutrisi pakan awal perlu diketahui dalam hubungannya dengan aktivitas enzim pencernaan yang akan berdampak terhadap pertumbuhan dan sintasannya.

Tiga jenis pakan (gonad kerang, kuning telur ayam, dan rotifer) telah dicoba sebagai ransum pakan awal pada pemeliharaan larva kerapu sunu (Plectropomus leopardus) dan mampu meningkatkan sintasan hingga 3,97\% (Aslianti et al., 2008). Ditinjau dari ukuran bukaan mulut larva ikan kuwe pada D- 2 mempunyai ukuran sebesar $112 \pm 34 \mu \mathrm{m}$ (Hadi, 2009), sedangkan ukuran partikel gonad kerang $(62,84 \pm 3,87 \mu \mathrm{m})$ dan partikel emulsi kuning telur $(73,44 \pm 14,82 \mu \mathrm{m})$; jauh lebih kecil daripada ukuran bukaan mulut larva. Oleh karenanya kedua jenis pakan tersebut relatif cocok dan dapat digunakan sebagai pakan awal pada pemeliharaan larva ikan kuwe. Sementara rotifer yang tersedia dan digunakan dalam penelitian ini mempunyai kisaran ukuran lebih besar (140-200 $\mu \mathrm{m}$ ) daripada ukuran bukaan mulut larva. Namun demikian selama pemeliharaan larva, sering kali rotifer dalam wadah pemeliharaan berkembang biak dan menghasilkan nauplii- nauplii yang berukuran kecil (< $140 \mathrm{~mm}$ ), sehingga larva ikan yang dipelihara dapat memanfaatkannya. Penggunaan rotifer dalam penelitian ini dimaksudkan sebagai pembanding walaupun ukurannya lebih besar daripada ukuran bukaan mulut larva ikan kuwe. Jenis pakan awal yang sesuai (ukuran dan nutrisinya) dapat meningkatkan aktivitas enzim pencernaan dan diprediksi mempunyai korelasi positif terhadap pertumbuhan sehingga sintasan larva dapat ditingkatkan. Dengan mengetahui aktivitas enzim pencernaan larva maka dapat ditentukan jenis pakan awal yang cocok dan sesuai serta mendukung sintasan larva terutama pada 
stadia awal yang merupakan stadia kritis. Hasil penelitian diharapkan dapat mendukung peningkatan produksi benih ikan kuwe sehingga usaha budidaya pembesaran hingga ukuran konsumsi dapat berkesinambungan.

\section{BAHAN DAN METODE}

Penelitian dilakukan di hatcheri ikan laut Balai Besar Penelitian dan Pengembangan Budidaya Laut (BBPPBL) Gondol, Bali dengan menggunakan 9 buah wadah berupa bak fiber berbentuk silinder berkapasitas $1 \mathrm{~m}^{3}$. Setiap wadah diisi air laut (33- 34 ppt) sebanyak $600 \mathrm{~L}$ dan telur ikan kuwe dengan kepadatan 10.000 butir/bak. Larva yang menetas setelah dihitung daya tetasnya (hatching rate), mulai D- 2-D- 10 dipelihara dengan pemberian pakan awal berbeda yang merupakan perlakuan yakni (A) rotifer, (B) gonad kerang, dan (C) kuning telur. Setiap perlakuan diulang 3 kali. Jumlah pakan yang diberikan disesuaikan dengan perkembangan larva, selanjutnya pakan buatan komersial (powder ukuran 200-300 $\mu \mathrm{m}$ ) dan nauplii Artemia diberikan hingga larva mencapai stadia yuwana (D-30). Prosedur pemberian pakan dijelaskan dalam Diagram 1, sedangkan pengaruh perbedaan jenis pakan awal terhadap pertumbuhan dan sintasan benih dapat diketahui melalui analisis sidik ragam. Pengamatan pertumbuhan panjang total dan bobot badan dilakukan setiap hari selama 10 hari (hingga D-10), selanjutnya setiap 5 hari yaitu pada D- 15, D- 20, D- 25, dan D- 30 (saat dilakukan panen). Pengambilan sampel dari masing-masing perlakuan di- lakukan secara acak sebanyak 10 ekor, sedangkan sintasan benih dihitung pada akhir penelitian (D-30).

Untuk mengetahui aktivitas enzim pencernaan larva (protease, amilase, dan lipase) dari masing-masing perlakuan dilakukan pengambilan sampel pada kondisi suhu $0^{\circ} \mathrm{C}-4^{\circ} \mathrm{C}$ sebanyak $0,5-1 \mathrm{~g}$ atau \pm 1.000 ekor pada larva D- 1-D- 10, dan 100- 500 ekor pada larva D- 15, D- 20, D- 25, dan D- 30. Analisis enzim dilakukan di Laboratorium Nutrisi BBPPBL Gondol dengan menggunakan metode Bergmeyer \& Grassl (1983) dan menggunakan alat spektrofotometer dengan panjang gelombang 340- $560 \mathrm{~nm}$. Pengukuran aktivitas enzim diawali dengan mengekstraksi sampel dengan cara menghaluskan (digerus) untuk mendapatkan substratnya.

Aktivitas enzim protease ditentukan dengan mengukur kemampuan enzim dalam menghidrolisis protein sehingga dihasilkan tirosin yang dibebaskan. Pengukuran dilakukan dengan menggunakan substrat kasein dan tirosin sebagai standar dengan menggunakan alat spektrofotometer (Suryanti, 2002).

Aktivitas enzim amilase diketahui dengan cara mengukur kemampuan enzim untuk menghidrolisis larutan pati hingga dibebaskan gula pereduksi. Gula pereduksi yang dihasilkan diukur dengan metode Shaffer Hartman dan automatic analysis Bochringer Mannheimamilase PNP (Suryanti, 2002).

Aktivitas enzim lipase diukur dengan menggunakan substrat triolein. Asam lemak

\section{Pengelolaan pakan Feeding management}

Umur larva (hari) Day after hatching (day)
Nannochloropsis (sel (cell)/ mL)

Perlakuan (Treatment):
A. Rotifer (ind./ $\mathrm{mL}$ )
B. Gonad kerang (Trochopor) (g)
C. Kuning telur (Egg yolk emulsion) (g)
Pakan buatan (Artificial feed) (g)
Nauplii Artemia (Artemia nauplii) (ind./ mL)

\section{$\begin{array}{llllll}0-1 & 2-10 & 11-15 & 16-20 & 21-25 & 26-30\end{array}$}

Diagram 1. Skema prosedur pemberian pakan masing- masing perlakuan selama pemeliharaan
larva ikan kuwe hingga mencapai fase yuwana $\left(D_{30}\right)$

Diagram 1. Schematic representation feeding management of each treatment while golden trevally larval reared up to juvenile stage $\left(D_{30}\right)$ 
yang dibebaskan akan membentuk garam asam lemak yang mengendap, selanjutnya garam tersebut diukur secara turbidimetrik pada panjang gelombang $340 \mathrm{~nm}$ (Suryanti, 2002). Aktivitas enzim protease, amilase, dan lipase masing- masing dinyatakan dalam unit aktivitas enzim/ $\mathrm{mL}$ sampel/menit (Affandi et al., 1994).

Sebagai data dukung terhadap aktivitas enzim pada larva, dilakukan pula pengamatan kualitas air selama pemeliharaan hingga penelitian berakhir.

\section{HASIL DAN BAHASAN}

Diagram hasil analisis masing-masing aktivitas enzim pencernaan (protease, amilase, dan lipase) dari setiap perlakuan disajikan pada Gambar 1.

Dari Gambar 1, dapat diketahui bahwa aktivitas enzim protease, amilase, dan lipase pada semua perlakuan menunjukkan pola aktivitas yang relatif sama yaitu meningkat pada D- 2, kemudian menurun pada D- 3-D- 7 dan cenderung stabil hingga D- 30. Hal ini menunjukkan bahwa enzim pencernaan larva mulai aktif seiring dengan mulainya larva menerima pakan exogenus. Meningkatnya aktivitas enzim protease, amilase, dan lipase pada D- 2 menunjukkan bahwa proses metabolisme pakan pada organ pencernaan larva mengandung asam amino, zat pati, dan lemak yang selanjutnya akan dihidrolisis oleh enzim protease, amilase, dan lipase yang menghasilkan energi bebas, sehingga larva memperoleh energi dari hasil katabolisme asam amino fosfolipid. Meningkatnya aktivitas enzim pencernaan oleh adanya substrat makanan yang dikonsumsi oleh larva (yaitu rotifer, gonad kerang, dan kuning telur) memberikan kontribusi sebagai enzim eksogenus yang memicu perkembangan larva karena aktivitas enzim- enzim tersebut sangat berkaitan dengan perkembangan alat pencernaan yang sudah mulai sempurna dan sudah dapat dibedakan antara usus, saluran pencernaan (pylorus), dan lambung. Dengan bertambahnya umur larva, maka alat pencernaan akan berkembang sehingga mempengaruhi produksi enzim pencernaan karena enzim tersebut diproduksi oleh kelenjar pankreas, lambung, dan dinding usus (Kapoor et al., 1975 dalam Suryanti, 2002).

Berdasarkan persamaan regresi, hubungan antara aktivitas masing- masing enzim dan umur larva, terlihat bahwa aktivitas enzim protease (Gambar 2) pada ketiga perlakuan menunjukkan pola polinomial relatif sama, dengan nilai $R$ berturut- turut adalah $(A) R^{2}=0,2049 ;(B) R^{2}=0,16$; dan (C) $R^{2}=0,2086$. Hal ini menunjukkan bahwa persentase hubungan antara aktivitas enzim protease dengan umur larva pada semua perlakuan berkisar antara 16,0\% 20,8\%

Demikian halnya dengan persamaan regresi, hubungan antara aktivitas enzim amilase dan umur larva (Gambar 3), menghasilkan nilai $R$ berturut- turut $(A) R^{2}=0,2294$; (B) $R^{2}=0,2008$; dan (C) $R^{2}=0,2023$ sehingga persentase hubungan antara aktivitas enzim amilase dengan umur larva berkisar antara $20,00 \% 22,94 \%$

Sedangkan persamaan regresi hubungan antara aktivitas enzim lipase dan umur larva (Gambar 4), menghasilkan persamaan dengan nilai $R$ berturut-turut (A) $R^{2}=0,7534$; (B) $R^{2}=0,9062$; dan $(C) R^{2}=0,6608$ yang menunjukkan bahwa persentase hubungan berkisar antara $66,08 \% 90,62 \%$

Dari persamaan regresi hubungan antara aktivitas ketiga enzim dengan umur larva tersebut, terlihat bahwa persentase aktivitas enzim lipase cenderung lebih tinggi $(66,08 \%$ $90,62 \%$ daripada persentase aktivitas enzim protease $(16,0 \% 20,8 \%$ maupun amilase $(20,00 \%$ 22,94\%). Hal ini menunjukkan bahwa lemak (lipid) yang terkandung dalam pakan awal (rotifer, gonad kerang, dan kuning telur) mempunyai peran penting dalam proses metabolisme sehingga dihasilkan enzim pencernaan yang dapat memacu perkembangan organ tubuh sesuai dengan bertambahnya umur larva. Hasil penelitian Palinggi et al. (2002), terhadap ikan kuwe (Caranx sexfasciatus) yang masih satu famili (Carangidae) dengan Gnathanodon speciosus terlihat adanya perbedaan pertambahan panjang badan pada ikan kuwe yang diberi pakan dengan sumber lemak berbeda. Selanjutnya dikatakan bahwa ikan kuwe yang pakannya ditambah dengan minyak ikan, memperlihatkan pertumbuhan panjang tertinggi $(2,2 \mathrm{~cm} /$ ind.) dibandingkan dengan ikan yang dalam pakannya diberi tambahan minyak cumi $(1,2 \mathrm{~cm} /$ ind.) ataupun dengan tambahan campuran antara minyak ikan + minyak cumi + minyak kedelai $(1,9 \mathrm{~cm} /$ ind.). Kondisi ini didukung dengan hasil analisis proksimat (Tabel 1) bahwa kandungan lemak pada masing-masing jenis pakan awal juga 

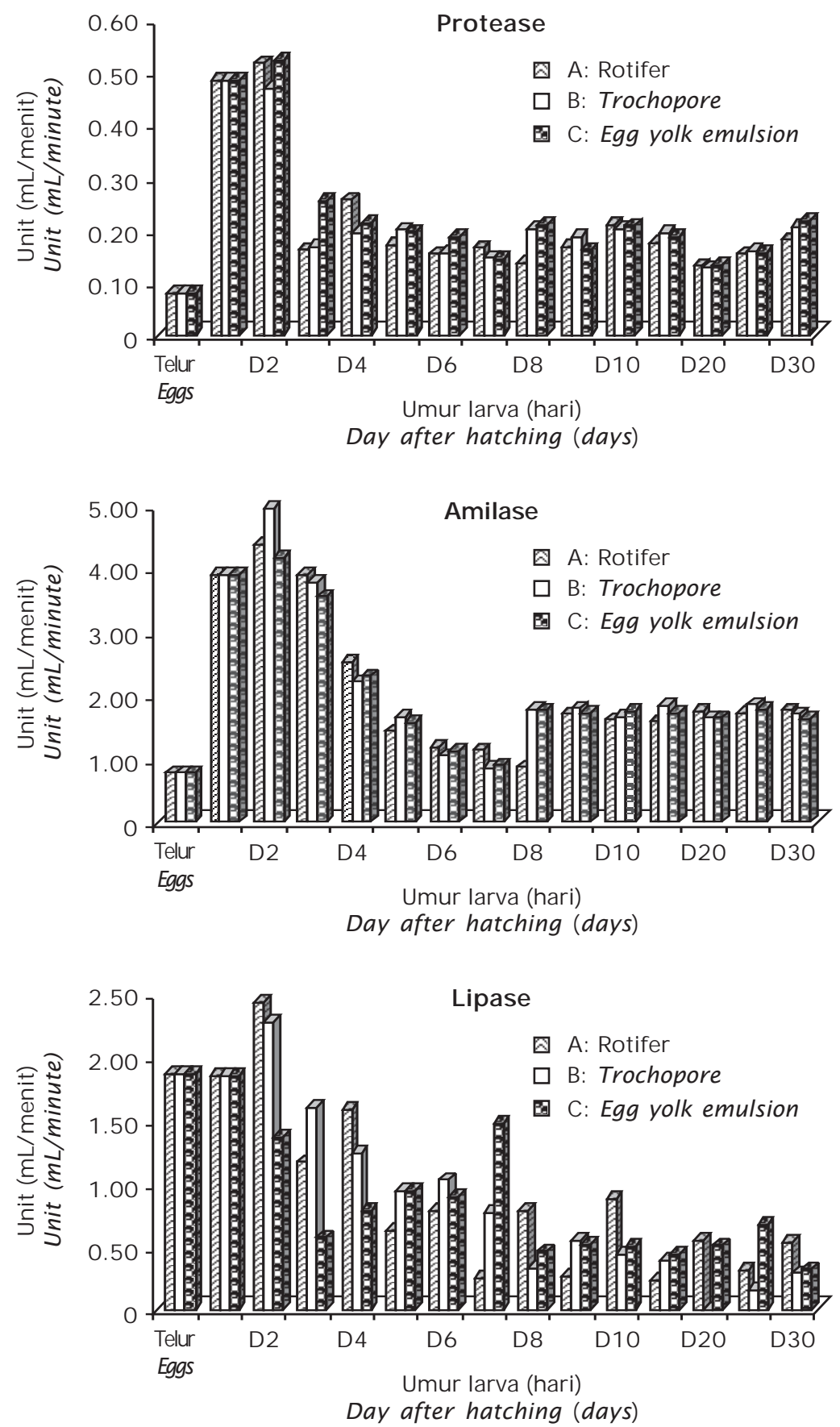

Gambar 1. Diagram aktivitas enzim pencernaan (protease, amilase, dan lipase) larva ikan kuwe dari setiap perlakuan pakan awal (rotifer, gonad kerang, dan kuning telur) selama penelitian

Figure 1. Schematic of digest enzymes activity (protease, amylase, and lipase) of each treatment with different initial feed (rotifer, trochopor, and egg yolk emulsion) while experiment 


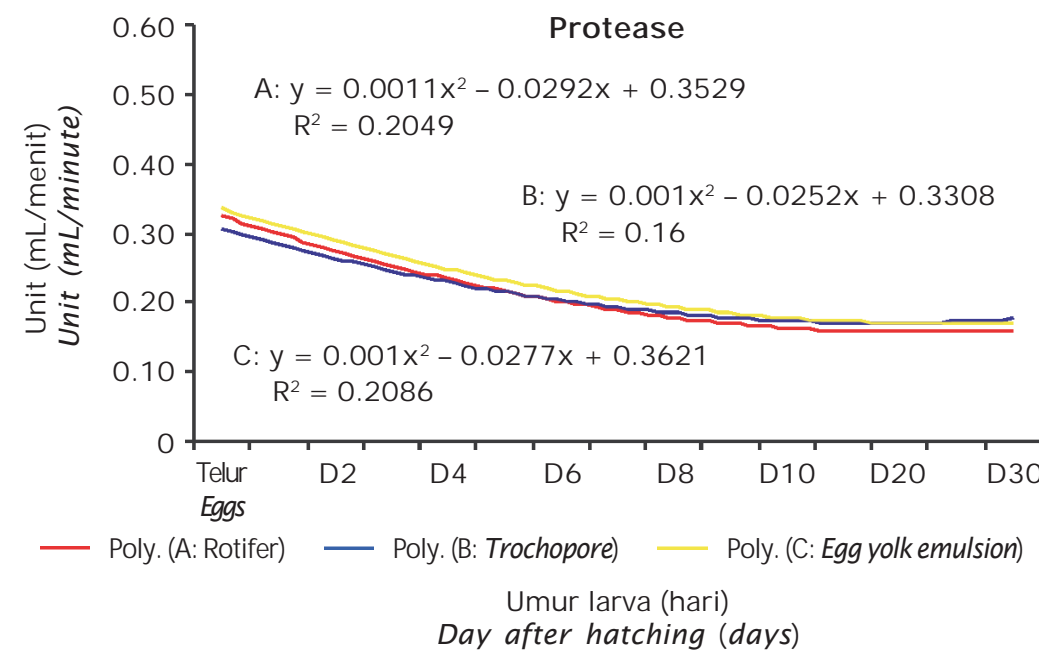

Gambar 2. Diagram korelasi antara aktivitas enzim protease dan umur larva ikan kuwe dari masing- masing perlakuan

Figure 2. Correlation between protease enzyme activity and age of golden trevally larvae of each treatment

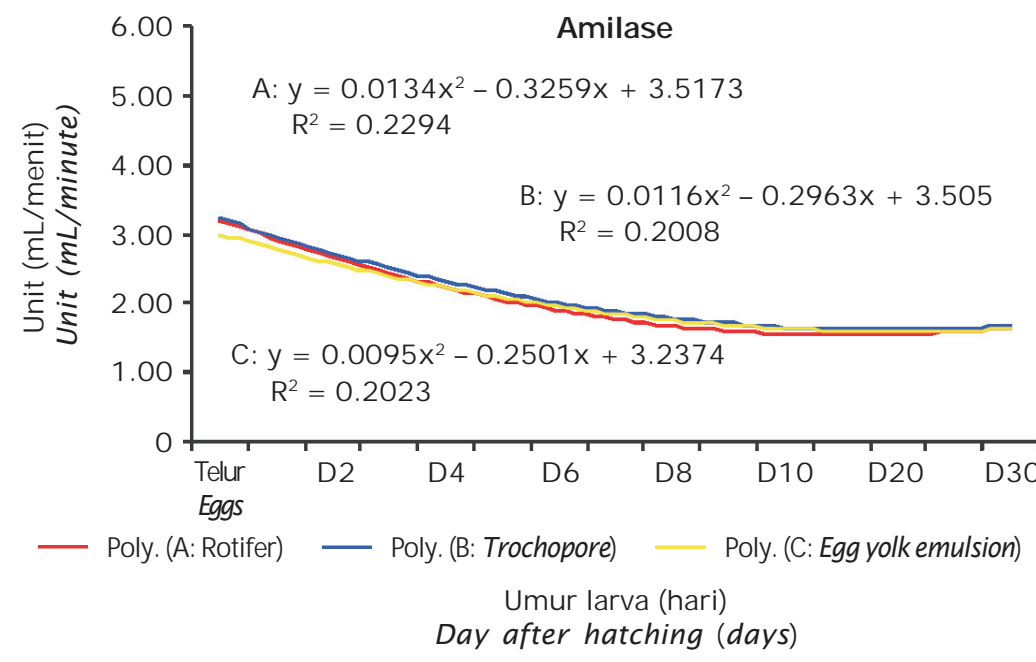

Gambar 3. Diagram korelasi antara aktivitas enzim amilase dan umur larva ikan kuwe dari masing- masing perlakuan pakan awal

Figure 3. Correlation between amylase enzyme activity and age of golden trevally larvae of each treatment

berbeda dan terlihat lemak pada kuning telur jauh lebih tinggi $(63,49 \%)$ daripada rotifer $(17,28 \%)$ ataupun gonad kerang $(13,43 \%$.

Adapun aktivitas enzim yang menurun pada D- 3-D- 7 diduga bahwa larva berada pada fase perkembangan organ spesifik seperti pertumbuhan sirip punggung, sirip dada ataupun perkembangan kesempurnaan tulang belakang. Sesuai dengan pendapat Asmanik et al. (2007) bahwa salah satu faktor yang mempengaruhi pertumbuhan dan perkembangan tulang belakang ikan kuwe adalah kandungan nutrisi pakan yang diberikan selama masa pemeliharaan. Dikatakan pula oleh 


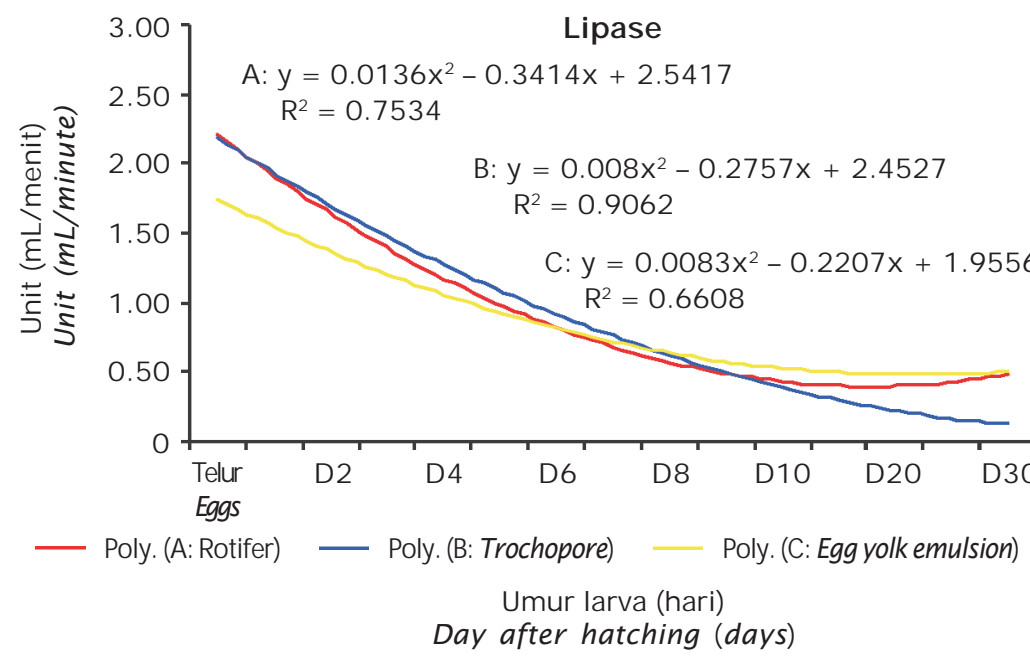

Gambar 4. Diagram korelasi antara aktivitas enzim lipase dan umur larva ikan kuwe dari masing- masing perlakuan pakan awal

Figure 4. Correlation between lipase enzyme activity and age of golden trevally larvae of each treatment

Tabel 1. Ukuran pakan awal dan komposisi nutrien hasil analisis proksimat serta asam lemak dalam pemeliharaan larva ikan kuwe, golden trevally

Table 1. Size of initial feed and nutrient composition of proximate and fatty acid analyzed on golden trevally larval reared

\begin{tabular}{|c|c|c|c|c|c|}
\hline \multirow{3}{*}{$\begin{array}{l}\text { Parameter } \\
\text { Parameters }\end{array}$} & \multicolumn{3}{|c|}{ Perlakuan (Treatments) } & \multirow{3}{*}{$\begin{array}{c}\text { Pakan } \\
\text { buatan } \\
\text { Artificial } \\
\text { feed } \\
\text { (g) }\end{array}$} & \multirow{3}{*}{$\begin{array}{c}\text { nauplii } \\
\text { Artemia } \\
\text { Artemia } \\
\text { nauplii } \\
\text { (ind./ mL) }\end{array}$} \\
\hline & $\mathbf{A}$ & B & C & & \\
\hline & $\begin{array}{l}\text { Rotifer } \\
\text { Rotifer } \\
\text { (ind./ mL) }\end{array}$ & $\begin{array}{c}\text { Gonad kerang } \\
\text { Trochopor } \\
\text { (g) }\end{array}$ & $\begin{array}{l}\text { Kuning telur } \\
\text { Egg yolk } \\
\text { emulsion (g) }\end{array}$ & & \\
\hline Ukuran (Size ) ( $\mu \mathrm{m})$ & $140-200$ & 62.84 & 73.44 & 48.44 & $>500$ \\
\hline Protein (Protein) $(\%$ & 66.31 & 42.24 & 29.93 & 48.00 & 54.48 \\
\hline Lemak (Lipid) (\%) & 17.28 & 13.43 & 63.49 & 28.00 & 16.78 \\
\hline Serat (Fiber) $(\%)$ & 6.29 & 6.42 & 0.57 & 1.00 & 3.80 \\
\hline Abu $($ Ash $)(\%$ & 5.13 & 10.86 & 5.50 & 7.00 & 8.10 \\
\hline EPA $(\%$ & 7.700 & 10.403 & - & - & 2.433 \\
\hline $\mathrm{DHA}(\%)$ & 0.121 & 4.858 & - & - & 0.042 \\
\hline Total $\omega-3$ HUFA & 10.988 & 16.608 & - & 16.825 & 2.676 \\
\hline
\end{tabular}

Kitajima et al. (1994) dalam Aslianti (2005) yang menyatakan bahwa kekurangan nutrisi pada rotifera dan nauplii Artemia akan mengakibatkan pertumbuhan gelembung renang yang rendah dan berdampak pada meningkatnya lordosis (kelainan tulang belakang) pada larva ikan red sea bream.
Berdasarkan pengamatan pertumbuhan panjang, bobot, dan korelasinya terhadap umur larva pada perlakuan C (kuning telur) (Gambar 5), menunjukkan bahwa pertumbuhan panjang dan bobot badan mempunyai korelasi yang positif dengan pertambahan umur larva yang dinyatakan dengan persamaan regresi 

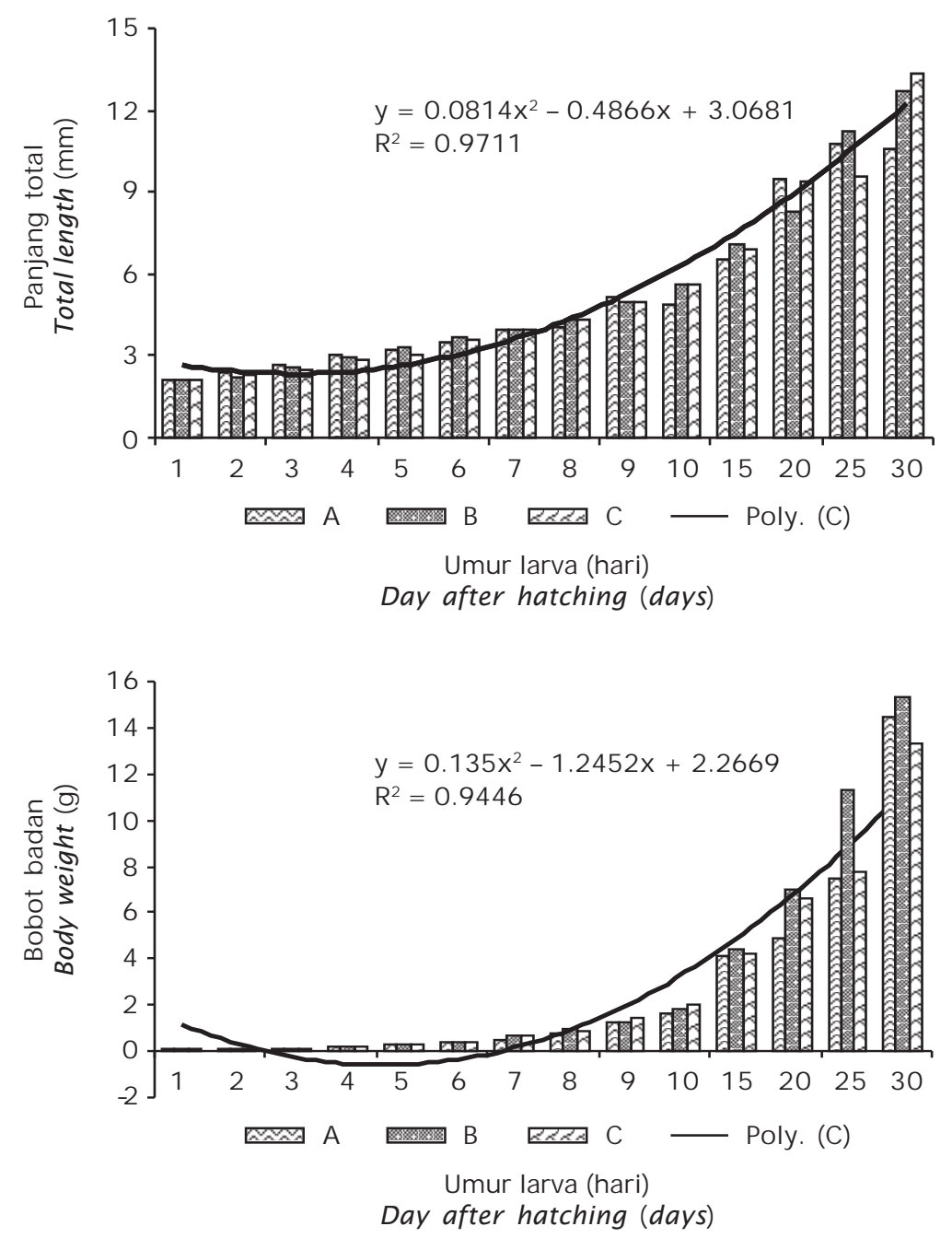

Gambar 5. Diagram korelasi hubungan panjang dan bobot badan dengan umur larva ikan kuwe pada perlakuan C (kuning telur)

Figure 5. Diagram of correlation between total length and body weight with age of golden trevally larvae of treatment C legg yolk emulsion)

polinomial berturut- turut untuk panjang badan adalah $Y=0,0814 x^{2}-0,4866 x+3,0681$ $\left(R^{2}=0,9711\right)$ dan untuk bobot badan adalah $Y=$ $0,135 x^{2}-1,2452 x+2,2669\left(R^{2}=0,9446\right)$. Hal ini menunjukkan bahwa persentase korelasi antara panjang badan dan bobot badan perlakuan C terhadap umur larva masingmasing adalah sebesar 97,11\%dan 94,46\%

Dari hasil pengamatan pertumbuhan (panjang total) pada akhir penelitian (D-30) menunjukkan bahwa larva yang diberi pakan awal kuning telur terlihat lebih tinggi $(13,3 \pm 1,77 \mathrm{~mm})$ daripada rotifer $(10,6 \pm 1,51 \mathrm{~mm})$ ataupun gonad kerang $(12,7 \pm 2,67 \mathrm{~mm})$, namun secara statistik tidak berbeda nyata $(P>0,05)$. Demikian juga sintasan yang dihasilkan pakan awal kuning telur menunjukkan nilai lebih tinggi $(55,42 \%)$ daripada rotifer $(52,42 \%)$ maupun gonad kerang $(52,45 \%$ (Tabel 2$)$.

Hasil pengamatan kualitas air selama pemeliharaan Iarva disajikan pada Tabel 3. Dalam hal ini kualitas air pemeliharaan terlihat 
Tabel 2. Hasil pengamatan pertumbuhan (panjang dan bobot badan) pada akhir penelitian (D- 30) serta nilai sintasan dari masing- masing perlakuan

Table 2. Observation of growth (total length and body weight) at the end experiment (D-30) and survival rate of each treatment

\begin{tabular}{lccc}
\hline \multirow{1}{*}{$\begin{array}{c}\text { Parameter } \\
\text { Parameters }\end{array}$} & A & B & Cerlakuan (Treatments) \\
\cline { 2 - 4 } & $\begin{array}{c}\text { Rotifer } \\
\text { Rotifer }\end{array}$ & $\begin{array}{c}\text { Gonad kerang } \\
\text { Trocophore }\end{array}$ & $\begin{array}{c}\text { Kuning telur } \\
\text { Egg yolk emulsion }\end{array}$ \\
\cline { 2 - 4 } & $10.6 \pm 1.51^{\mathrm{a}}$ & $12.7 \pm 2.67^{\mathrm{a}}$ & $13.3 \pm 1.37^{\mathrm{a}}$ \\
$\begin{array}{l}\text { Panjang total } \\
\text { Total length (mm) } \\
\text { Bobot badan } \\
\begin{array}{l}\text { Body weight }(\mathrm{g}) \\
\text { Sintasan }\end{array}\end{array}$ & 14.49 & 15.29 & 13.31 \\
Survival rate $(\%)$ & 52.42 & 52.45 & 55.42 \\
\hline
\end{tabular}

Keterangan (Note):

Nilai dalam kolom yang diikuti dengan huruf sama menunjukkan tidak berbeda nyata Values in column followed by the same superscript are not significantly different $(P>0.05)$

Tabel 3. Data kualitas air selama pemeliharaan larva ikan kuwe

Table 3. Value of water quality during larval reared of golden trevally

\begin{tabular}{lc}
\hline \multicolumn{1}{c}{$\begin{array}{c}\text { Parameter } \\
\text { Parameters }\end{array}$} & $\begin{array}{c}\text { Kisaran nilai } \\
\text { Range of value }\end{array}$ \\
\hline Suhu & $26-28$ \\
Temperature $\left({ }^{\circ} \mathrm{C}\right)$ & \\
Salinitas & $35-36$ \\
Salinity (ppt) & $8.11-8.25$ \\
$\mathrm{pH}$ & $0.108-0.418$ \\
$\mathrm{NH}_{3}(\mathrm{mg} / \mathrm{L})$ & $0.027-0.503$ \\
$\mathrm{NO}_{2}(\mathrm{mg} / \mathrm{L})$ & $0.065-0.73$ \\
$\mathrm{NO}_{3}(\mathrm{mg} / \mathrm{L})$ & $0.038-0.332$ \\
$\mathrm{PO}_{4}(\mathrm{mg} / \mathrm{L})$ & \\
\hline
\end{tabular}

masih terjaga dan cukup mendukung kehidupan larva hingga akhir penelitian (D- 30). Pembersihan dasar wadah melalui alat sipon dan pergantian air sebesar $25 \% 50 \%$ secara bertahap yang dilakukan mulai D- 10 nampaknya cukup mendukung kehidupan larva. Kondisi kualitas air yang mendukung pada gilirannya dapat memperbaiki pertumbuhan dan meningkatkan sintasan larva hingga dihasilkan benih dengan kisaran sintasan sebesar 52,42\% 55,42\% Dari hasil penelitian ini nampaknya sintasan benih dapat diperbaiki dan ditingkatkan dibanding penelitian yang pernah dilakukan oleh Setiadharma et al. (2008) yang menghasilkan sintasan $\pm 14 \%$

Selama pemeliharaan larva ikan kuwe, suhu air bervariasi antara $26^{\circ} \mathrm{C}-28^{\circ} \mathrm{C}$ dan salinitas antara 35- 36 ppt. Sebagai bahan perbandingan dengan ikan kuwe (Caranx sexfasciatus), yang dipelihara Palinggi et al. (2002), bahwa suhu air selama penelitian berkisar antara $28^{\circ} \mathrm{C}-29^{\circ} \mathrm{C}$ dan salinitas 29 ppt. Dengan demikian dapat diketahui bahwa ikan kuwe (Gnathanodon speciosus) pada penelitian ini masih toleran dengan suhu sekitar $26^{\circ} \mathrm{C}$ dan salinitas $\pm 35 \mathrm{ppt}$.

Derajat keasaman air $(\mathrm{pH})$ berkisar 8,118,25 . Kisaran tersebut masih layak bagi pertumbuhan ikan. Dalam Boyd (1990) dinyatakan bahwa $\mathrm{pH}$ yang baik untuk kehidupan ikan berkisar 6,5- 9,0.

Kadar amoniak dan nitrit selama penelitian masing- masing berkisar 0,108-0,418 mg/ L dan 0,027- 0,503 mg/ L. Upaya untuk menjaga agar kondisi kualitas air tetap optimal yaitu dengan cara melakukan penyiponan dan pergantian air setiap 2 hari sebanyak 25\% 50\% yang dimulai dari D- 10. Pescod (1973) dalam Setiawati et al. (2005) menyatakan bahwa 
kandungan amoniak sebaiknya tidak melebihi $1 \mathrm{mg} / \mathrm{L}$ untuk perairan tropik. Sedangkan nitrit merupakan produk perantara dalam oksidasi amoniak dan dapat menyebabkan tidak berfungsinya haemoglobin $(\mathrm{Hb})$ dalam transfer oksigen karena bentukan metahemoglobin $\left(\mathrm{HbNO}_{2}\right)$. Kandungan nitrit, nitrat, amoniak, dan fosfat dalam penelitian ini terlihat masih relevan dan mendukung kehidupan Iarva sehingga sintasan benih yang dihasilkan pada akhir penelitian (D-30) cukup tinggi berkisar $52,42 \% 55,42 \%$

\section{KESIMPULAN}

- Aktivitas enzim pencernaan (protease, amilase, dan lipase) dari ketiga perlakuan pakan awal menghasilkan korelasi positif terhadap pertumbuhan larva ikan kuwe.

- Kuning telur dapat digunakan sebagai pakan awal sebelum larva mampu mengkonsumsi rotifer dan menghasilkan sintasan tertinggi.

\section{UCAPAN TERIMA KASIH}

Terima kasih yang amat sangat disampaikan kepada Sdr. Akhmad Gufron Arif, Wiwin Adiwinata, dan Katimin selaku teknisi litkayasa bidang larva rearing; Sdr. Darsudi selaku teknisi litkayasa bidang nutrisi, juga Sdri. Ni Putu Ayu Kenak dan Ni Kadek Ariani selaku teknisi litkayasa bidang kualitas air atas peran serta dan partisipasinya dalam membantu pelaksanaan penelitian ini hingga selesai.

\section{DAFTAR ACUAN}

Afifah, Aslianti, T., \& Hadi, C.S. 2010. Pola pemangsaan dan pertumbuhan larva ikan kuwe (Gnathanodon speciosus) berdasarkan jenis pakan awal yang diberikan. Prosiding Forum Inovasi Teknologi Akuakultur 2010 Buku 2. Puslitbang Perikanan Budidaya, hlm. 633- 638.

Affandi, R., Mokoginta, I., \& Suprayudi, A. 1994. Perkembangan enzim pencernaan benih ikan gurame, Osphronemus goramy, Lacapede. J. Ilmu-ilmu Perairan dan Perikanan Indonesia, II(2): 63- 71.

Aslianti, T. 2005. Evaluasi kualitas benih kerapu macan, Epinephelus fuscoguttatus produksi beberapa hatchery di Bali berdasarkan pengamatan pertumbuhan tulang belakang. Fakultas Teknologi Kelautan dan Perikanan. Universitas Hang Tuah Surabaya. J. Perikanan, I(2): 56- 62.
Aslianti, T., Suwirya, K., \& Asmanik. 2008. Teknologi pemeliharaan larva kerapu sunu (Plectropomus leopardus) secara massal. Puriskan Budidaya. Badan Riset Kelautan dan Perikanan. J. Ris. Akuakultur, 3(1): 1- 11.

Asmanik, Aslianti, T., \& Setiadharma, T. 2007. Pengamatan awal perkembangan dan pertumbuhan tulang belakang larva ikan kuwe, Golden trevally (Gnathanodon speciosus, Forsskal). Buku Pengembangan Teknologi Budidaya Perikanan. Badan Riset Kelautan dan Perikanan Tahun 2007, hlm. 456- 460.

Bergmeyer, H.V. \& Grassl, M.G.1983. Determination with glucose oxidize and peroxidese: Methods of enzymatic analysis. $2^{\text {nd }}$ edition. verlag chemie weinhem, $p$. 1,205- 1,202.

Boyd, C.E. 1990. Water quality in ponds for aquaculture. Aburn University. Alabama USA, $482 \mathrm{pp}$.

Hadi, C.S. 2009. Pengaruh perbedaan jenis pakan awal terhadap sifat biologi larva ikan kuwe (Gnathanodon speciosus). Skripsi. Mahasiswa Fak. Pertanian, Jurusan Perikanan Universitas Gadjah Mada. Yogyakarta, $89 \mathrm{hlm}$.

Hepher, B. 1988. Nutrition of Pond Fishes. Cambridge University Press, Cambridge, New York, $388 \mathrm{pp}$.

Kordi, K.M.G.H. 2005. Budidaya ikan laut di Karamba Jaring Apung. Penerbit Rineka Cipta. Jakarta, hlm. 33-40.

Palinggi, N.N., Rachmansyah, \&Usman. 2002. Pengaruh Pemberian Sumber Lemak Berbeda dalam Pakan Terhadap Pertumbuhan Ikan Kuwe, Caranx sexfasciatus. Badan Riset Kelautan dan Perikanan. Departemen Kelautan dan Perikanan. J. Pen. Perik. Indonesia, (8)3: 25- 29.

Peristiwadi. 2006. Ikan-ikan laut ekonomis penting di Indonesia. Petunjuk identifikasi. LIPI. Jakarta, hIm. 93- 94.

Setiadharma, T., Syahidah, D., Alit, A.A.K., \& Priyono, A. 2008. Pengkayaan pakan alami jenis rotifera terhadap peningkatan keragaman benih ikan kuwe (Gnathanodon speciosus Forsskal). Prosiding Teknologi Perikanan Budidaya 2008. Puriskan Budidaya, hIm. 289- 293.

Setiawati, K.M., Melianawati, R., Supii, A.I., \& Johnny, F.R. 2005. Studi Pendahuluan Pemeliharaan Benih Kakap Merah (Lutjanus argentimaculatus) pada Salinitas yang Berbeda. Buku Perikanan Budidaya Ber- 
kelanjutan. Pusat Riset Perikanan Budidaya. Badan Riset Kelautan dan Perikanan, hlm. 142- 149.

Shobo, M. 1991. Aquaculture in Tropical Areas. (Eds.) Shokita, S., Kakazu, K., Tomori, A., \& Toma, T. English edition prepared by:
Yamaguchi, M. Midori Shobo Co., Ltd. Tokyo, p. 146- 149.

Suryanti, Y. 2002. Perkembangan aktivitas enzim pencernaan pada larva/ benih ikan baung (Mystus nemurus C.V.), J. Pen. Perik. Indonesia, 8(3): 15- 18. 